\title{
HUBUNGAN ANEMIA DENGAN KEJADIAN ABORTUS DI RSUD DR. H. ABDUL MOELOEK PROVINSI LAMPUNG
}

\author{
Relationship between Anemia and Incidence of Abortion in Hospitals dr. H. Abdul Moeloek \\ Lampung Province
}

\author{
Aryanti Wardiyah
}

\begin{abstract}
Akademi Keperawatan Malahayati Bandarlampung
Jalan Pramuka no 27 Kemiling Bandarlampung 35153

e-mail: gipho85@yahoo.com
\end{abstract}

\begin{abstract}
ABSTRAK
Abortus menunjukkan pengeluaran hasil kehamilan sebelum janin dapat hidup di luar kandungan, Komplikasi yang terjadi saat persalinan merupakan penyebab utama terjadinya kematian pada bayi yang semula hidup pada saat proses persalinan dimulai, tetapi kemudian lahir mati. Tujuan penelitian untuk diketahuinya hubungan anemia dengan kejadian abortus di RSUD DR. H. Abdul Moeloek Provinsi Lampung tahun 2014. Jenis penelitian ini adalah penelitian kuantitatif dengan desain penelitian survey analitik dengan pendekatan cross sectional. Penelitian dilakukan di RSUD DR. H. Abdul Moeloek dari bulan Oktober-Desember 2014. Populasi pada penelitian ini adalah seluruh ibu hamil yang dirawat $\leq 28$ minggu, baik yang abortus maupun yang tidak abortus yakni sebanyak 1.834 persalinan. jumlah sampel sebanyak 95 responden penelitian. Teknik sampling dalam penelitian ini menggunakan random sampling. Hasil penelitian menunjukkan ada hubungan anemia dengan kejadian abortus di RSUD Abdul Moeloek Tahun 2013. Menganjurkan kepada ibu untuk berupaya menjaga diri dari penyakit-penyakit yang memiliki resiko tinggi terhadap penyulit persalinan yang memerlukan tindakan Abortus. dan dapat memberikan motivasi ibu untuk melakukan antenatal care secara rutin serta melaksanakan perawatan kehamilan.
\end{abstract}

Kata Kunci : : Anemia, abortus

\section{ABSTRACT}

Abortion shows expenditure pregnancy outcomes before the fetus can live outside the womb, complications that occur during labor is a major cause of death in infants who originally lived on when labor starts, but then stillbirth.The aim of research for known relationship between anemia and incidence of abortion in hospitals DR. H. Abdul Moeloek Lampung Province in 2014. This research was a quantitative research design analytic survey research with cross sectional approach. The study was conducted at Hospital DR. H. Abdul Moeloek of the month from October to December 2014. The population in this study were all pregnant women who were treated $\leq 28$ weeks, both the abortion or not abortion that as many as 1,834 births. the total sample of 95 respondents of the study. Sampling techniques in this study using random sampling.The results showed no association of anemia with the incidence of abortion in hospitals Abdul Moeloek 2013. Suggestion: Advise the mother to seek to protect themselves from diseases that have a high risk of childbirth complications that require action abortion. and can provide maternal motivation to perform routine antenatal care and carry out maintenance of pregnancy.

Keywords : Anemia, Abortion

\section{LATAR BELAKANG}

Berdasarkan badan organisasi kesehatan dunia (WHO, 2006) persentase kemungkinan terjadinya abortus cukup tinggi. Sekitar 15$40 \%$ angka kejadian, diketahui pada ibu yang sudah dinyatakan positif hamil dan $60-75 \%$ angka abortus terjadi sebelum usia kehamilan mencapai 12 minggu. Diperkirakan frekuensi keguguran spontan berkisar antara 10-15\%. Namun demikian, frekuensi seluruh keguguran yang pasti sukar ditentukan, karena abortus buatan banyak yang tidak dilaporkan, kecuali bila telah terjadi komplikasi. Keguguran spontan hanya disertai gejala dan tanda ringan, sehingga wanita tidak datang ke dokter atau 
rumah sakit (Azhari, 2012; Glantz, 2007; Green, 2012).

Di Indonesia diperkirakan bahwa sekitar 2-2,5\% mengalami keguguran setiap tahun, sehingga secara nyata kejadian tersebut dapat menurunkan angka kelahiran menjadi 1,7 pertahunnya (Manuaba, 2009). Data Kemenkes tahun 2012 menyatakan bahwa angka kematian Ibu (AKI) sekitar 21,7\% terjadi karena abortus. Data ini mengalami kenaikan dibandingkan tahun sebelumnya, yaitu pada tahun 2011 kejadian abortus adalah sebesar 18,5\% (Kemenkes RI, 2014). Kejadian abortus diduga mempunyai efek terhadap kehamilan berikutnya, baik pada timbulnya penyulit kehamilan maupun pada hasil kehamilan itu sendiri. Wanita dengan riwayat abortus mempunyai risiko yang lebih tinggi untuk terjadinya persalinan prematur, abortus berulang, dan berat badan lahir rendah (BBLR) (Cunningham, 2005). Sedangkan data yang dikeluarkan oleh Dinas Kesehatan Propinsi Lampung mencatat bahwa kejadian abortus di Lampung pada tahun 2013 cukup tinggi yaitu berkisar 6.705 (26,39\%) dari 13.381 persalinan (Dinkes Prop. Lampung, 2013).

Data abortus di RSUD Abdoel Moeloek tercatat sebanyak 116 ibu pada tahun 2011 dan sebagian besar karena faktor ibu yaitu sebanyak 22,7\% ibu karena usia kehamilan resiko tinggi, $31,7 \%$ karena penyakit dan sisanya faktor lainnya. Pada tahun 2012 naik menjadi 123 kasus yang terdiri dari 36,1\% karena kehamilan pada usia resiko tinggi, $32,6 \%$ karena frekuensi paritas melahirkan lebih dari tiga kali (grandemultipara) $42 \%$ karena penyakit yang diderita ibu dan sisanya karena faktor lain. Pada Tahun 2013 sebanyak $18,5 \%$ ibu karena usia kehamilan resiko tinggi, $30,8 \%$ karena penyakit dan sisanya faktor lainnya (RSUD Abdul Moeloek, 2013). Ada 3 penyebab klasik kematian ibu yaitu perdarahan, keracunan kehamilan dan infeksi. Menurut Cunningham (2010), abortus merupakan salah satu penyebab perdarahan atau penyulit persalinan (Schaffer, 2014).

Berdasarkan penjelasan di atas, penelitian ini memfokuskan pada penelitian mengenai aspek abortus sebagai terjadinya penyulit persalinan yang faktor-faktor etiologis ditentukan berdasarkan faktor umum yang ada pada ibu. Faktor-faktor tersebut adalah usia, paritas, dan penyakit yang dialami ibu. Faktor lain yang berkaitan dengan faktor yang berhubungan dengan abortus adalah pengetahuan ibu tentang abortus meskipun tidak memiliki kaitan langsung dengan terjadinya abortus akan tetapi pengetahuan dapat membentuk perilaku-perilaku yang dapat menyebabkan terjadinya abortus, misalnya perilaku perawatan kehamilan, asupan makanan dan nutrisi, perilaku merokok, alkohol dan perilaku lain yang dapat menyebabkan terjadinya keracunan. Penelitian ini bertujuan untuk mengetahui hubungan antara anemia dengan kejadian abortus di RSUD DR. H. Abdul Moeloek Provinsi Lampung Tahun 2014.

\section{METODE}

Jenis penelitian ini adalah penelitian kuantitatif dengan rancangan penelitian survey analitik dengan menggunakan pendekatan cross sectional, alasan pemilihan rancangan ini didasarkan bahwa studi ini cocok untuk mempelajari kasus-kasus yang jarang dan disebabkan oleh lebih dari satu faktor penyebab. Lokasi penelitian dilakukan di RSUD DR. H Abdul Moeloek Provinsi Lampung, dengan menggunakan data rekam medik selama tahun 2013. Adapun waktu penelitian dilakukan pada bulan OktoberDesember 2014.

Populasi penelitian ini adalah seluruh ibu hamil yang dirawat $\leq 20$ minggu, baik yang abortus maupun yang tidak abortus di RSUD DR. H. Abdul Moeloek Provinsi Lampung Tahun 2013 pada bulan Januari sampai dengan Desember 2013 yaitu sebanyak 1.834 persalinan. Penentuan jumlah sampel dihitung dengan rumus Slovin, hasil perhitungan didapati jumlah sampel adalah sebesar 94,83 dan hasil pembulatan sampel yaitu sebesar 95 responden penelitian. Criteria sampel penelitian yaitu: Ibu bersalin yang dirawat di RSUD DR. H. Abdoel Moeloek Provinsi Lampung Tahun 2013. Periode perawatan dari bulan Januari sampai dengan Desember 2013. Melahirkan anak pertama, kedua dan seterusnya. 


\section{HASIL DAN PEMBAHASAN}

\section{Hasil Univariat}

Tabel 1. Distribusi Frekuensi Kejadian Abortus

\begin{tabular}{lcc}
\multicolumn{1}{c}{ Abortus } & Jumlah & Persen \\
\hline Abortus & 44 & 46,3 \\
\hline Tidak Abortus & 51 & 53,7 \\
\hline Total & 95 & 100,0
\end{tabular}

Berdasarkan tabel di atas, menunjukkan bahwa responden yang mengalami kejadian abortus adalah sebanyak 44 (46,3\%) responden, sedangkan yang tidak mengalami kejadian abortus sebanyak $51 \quad(53,7 \%)$ responden.

\section{Tabel 2. Distribusi Frekuensi Anemia}

\begin{tabular}{lcc}
\multicolumn{1}{c}{ Anemia } & Jumlah & Persen \\
\hline Anemia & 46 & 48,4 \\
\hline Tidak & 49 & 51,6 \\
\hline Total & 95 & 100
\end{tabular}

Berdasarkan tabel di atas, terdistribusi bahwa responden yang mengalami anemia adalah sebanyak $46(48,4 \%)$ responden, sedangkan responden yang tidak mengalami anemia adalah sebanyak $49 \quad(51,69 \%)$ responden.

\section{Hasil Bivariat}

Hubungan anemia dengan kejadian abortus, hasil uji statistik dengan menggunakan chi square diperoleh nilai $\mathrm{p}=0,000$ yang menunjukkan bahwa ada hubungan antara anemia dengan kejadian abortus di RSUD Abdul Moeloek Tahun 2014.

\section{Hubungan Anemia dengan Kejadian Abortus}

Kejadian abortus lebih dominan terjadi pada ibu dengan anemia yaitu sebanyak 40 $(87,0 \%)$ responden, sedangkan ibu yang tidak memiliki anemia sebagian besar adalah tidak mengalami abrotus sebanyak 45 (91,8\%) responden. Dengan demikian secara presentase ibu yang memiliki anemia lebih banyak yang mengalami kejadian abortus dibandingkan ibu yang tidak memiliki anemia.

Hasil uji statistik didapatkan nilai $\mathrm{P}_{\text {value }}=0,000$ yang berarti pada nilai $\alpha=0,05 \%$ adalah $\left(\mathrm{P}_{\text {value }}<0,05\right)$. Sehingga dapat disimpulkan ada hubungan antara anemia dengan kejadian abortus di RSUD Abdul Moeloek Tahun 2014. Adapun derajat keeratan hubungan 2 variabel dapat dilihat pada nilai $\mathrm{OR}=75,000(19,738-284,977)$, artinya ibu yang memiliki anemia mempunyai risiko mengalami kejadian abortus 15,0 kali dibandingkan ibu yang tidak memiliki anemia.

Hasil penelitian ini sejalan dengan teori yang kemukakan oleh Saifuddin (2006), bahwa anemia pada saat hamil dapat mengakibatkan efek yang buruk baik pada ibu maupun pada janin. Anemia dapat mengurangi suplai oksigen pada metabolisme ibu karena kekurangan kadar hemoglobin untuk mengikat oksigen yang dapat mengakibatkan efek tidak langsung pada ibu dan janin antara lain terjadinya abortus, selain itu ibu lebih rentan terhadap infeksi dan kemungkinan bayi lahir prematur.

Anemia dalam kehamilan yang disebabkan karena kekurangan zat besi, jenis pengobatannya relatif mudah, bahkan murah. Darah akan bertambah banyak dalam kehamilan yang lazim disebut Hidremia atau Hipervolemia. Akan tetapi, bertambahnya sel darah kurang dibandingkan dengan bertambahnya plasma sehingga terjadi pengenceran darah. Perbandingan tersebut adalah sebagai berikut: plasma $30 \%$, sel darah $18 \%$ dan haemoglobin $19 \%$.

Berdasarkan perolehan hasil penelitian yang telah dilakukan, membuktikan bahwa antara teori sebelumnya dan penelitian yang dilakukan oleh peneliti memiliki kesamaan hasil serta sejalan dengan penelitian yang sudah terungkap sebelumnya, bahwa anemia berhubungan dengan kejadian abortus. Sehingga dengan demikian peneliti berpendapat bahwa ibu harus rajin untuk melakukan pemeriksaan selama kehamilan dengan teratur, melakukan kunjungan ANC lengkap selama kehamilan, yang dimaksudkan untuk menghindari risiko terburuk terhadap kejadian abortus. Karena risiko anemia dengan prevalensi anemia yang tinggi dapat berakibat negatif seperti kekurangan $\mathrm{Hb}$ dalam darah 
mengakibatkan kurangnya oksigen yang dibawa/ ditransfer ke sel tubuh maupun ke otak. Sehingga dapat memberikan efek buruk pada ibu maupun pada bayi yang dilahirkan.Seorang wanita yang menderita anemia, misal berbagai jenis anemia hemolitik, herediter atau yang diperoleh seperti anemia karena malaria, cacing tambang, penyakit ginjal menahun, penyakit hati, tuberkulosis, sifilis tumor ganas, dan sebagainya, dan dapat menjadi hamil. Dalam hal ini menjadi lebih berat dan mempunyai pengaruh tidak baik terhadap ibu hamil dalam masa kehamilan, persalinan, nifas serta anak dalam kandungan. Anemia dalam kehamilan bukannya tanpa risiko. Pada dasarnya ibu hamil dapat mengalami keguguran, lahir sebelum waktunya, BBLR, perdarahan sebelum dan selama persalinan bahkan dapat mengakibatkan kematian pada ibu dan janinnya.

Pengaruh anemia pada janin dan kehamilan adalah terhadap bahaya selama kehamilan, antara lain: dapat terjadinya abortus, persalinan prematuritas, hambatan tumbuh kembang janin dalam rahim, mudah terjadinya infeksi, ancaman dekompensasi kordisi $(\mathrm{Hb}<6 \mathrm{gr} \%)$, mola hidatidosa, hiperemesis gravidarum, perdarahan antepartum, ketuban pecah dini. Sedangkan bahaya terhadap janin antara lain: Abortus, Berat badan lahir rendah (BBLR), dapat terjadi cacat bawaan, terjadinya kematian intrauterin, bayi mudah mendapatkan infeksi sampai kematian perinatal, kelahiran dengan anemia, persalinan prematuritas tinggi.

Pendapat tersebut ditambahkan lagi oleh Saifuddin (2006), bahwa anemia pada saat hamil dapat mengakibatkan efek yang buruk baik pada ibu maupun pada janin. Anemia dapat mengurangi suplai oksigen pada metabolisme ibu karena kekurangan kadar hemoglobin untuk mengikat oksigen yang dapat mengakibatkan efek tidak langsung pada ibu dan janin antara lain terjadinya abortus, selain itu ibu lebih rentan terhadap infeksi dan kemungkinan bayi lahir prematur.

Oleh karena itu, wanita memerlukan zat besi lebih tinggi dari laki-laki karena terjadinya menstruasi, pada saat kehamilan memerlukan tambahan kebutuhan zat besi untuk meningkatkan jumlah sel darah merah janin dan plasenta, ditambah karena darah ibu hamil selama kehamilan mengalami hemodilusi (pengenceran) dengan peningkatan volume $30-40 \%$ yang puncaknya pada kehamilan 32 minggu sampai 34 minggu. Makin sering seorang wanita mengalami kehamilan dan melahirkan, makin banyak kehilangan zat besi dan menjadi makin anemis (Cunningham, 2010).

Berdasarkan penjelasan tersebut di atas, maka penulis berpendapat bahwa faktor anemia sangat besar pengaruhnya terhadap kejadian abortus. Karena anemia dalam kehamilan dapat berakibat fatal mulai dari kelahiran prematur sampai kematian ibu dan bayi, kematian yang disebabkan anemia masih tersus berkembang berkaitan dengan anemia pada kehamilan. Sehingga bagi ibu hamil sebaiknya dapat memperhatikan konsumsi makanan yang dimakan dalam setiap harinya, terutama yang mengandung asupan zat besi dari makanan, jika tidak didapatinya asupan zat besi dari makanan maka wanita hamil dianjurkan untuk mengonsumsi tablet besi selama kehamilan. Dengan demikian, mengingat masih tingginya angka prevalensi anemia pada kehamilan dan fatalnya risiko yang diakibatkan, maka sangatlah penting bagi masyarakat dan para praktisi kesehatan untuk lebih memperhatikan masalah ini.

\section{SIMPULAN}

Distribusi frekuensi responden anemia sebanyak $46(48,4 \%)$ responden, dan tidak anemia sebanyak $49 \quad(51,69 \%)$ responden. Distribusi frekuensi responden dengan kejadian abortus sebanyak $44 \quad(46,3 \%)$ responden, dan tidak abortus sebanyak 51 $(53,7 \%)$ responden. Ada hubungan antara anemia dengan kejadian abortus di RSUD Abdul Moeloek Tahun 2013. Disarankan kepada peneliti selanjutnya untuk meneliti faktor lain yang dapat menyebabkan terjadinya abortus seperti faktor kelainan ovum, kelainan genitalia ibu, gangguan sirkulasi plasenta, dan antagonis rhesus melalui pengukuran langsung sehingga penelitian tentang abortus dapat ditinjau lebih lengkap. 


\section{DAFTAR PUSTAKA}

Azhari. (2012). Masalah Abortus dan Kesehatan Reproduksi Perempuan. Makalah Seminar Kelahiran Tidak diinginkan (aborsi) Dalam Kesejahteraan Reproduksi Remaja

Cunningham, F Gary. et all. (2010). Obstetri Williams 23 rd ed. USA : The McGraw-. Hill Companies

Dinas Kesehatan Propinsi Lampung. (2013). Data Profil Propinsi Lampung. Lampung

RSUD Abdul Moeloek. (2013). Data Profil RSUD Abdul Moeloek Lampung. Lampung

Glantz, S. (2007). Immigration/Obesity/Abortion....

Library Media Connection, 26(2), 9191.

Green,

B. (2012). Abortion/Advertising/Freedom of Information.... Library Media Connection, 31(2), 91-91.

Kemenkes RI. (2014). Profil Kesehatan Indonesia 2013. Jakarta.

Manuaba, I.B.G, (2009). Pengantar Kuliah Obstetri. Buku Kedokteran EGC. Jakarta.

Saifuddin. (2006). Pelayanan Kesehatan Maternal \& Neonatal. Yayasan Bina Pustaka Sarwono Prawirohardjo. Jakarta.

Schaffer, A. (2014). Too Much Information. [Article]. MIT Technology Review, 117(1), 73-76.

World Health Organization. (2006). Unsafe Abortion: Global and Regional Estimates of Incidence of and Mortality due to Unsafe Abortion with a Listing of Available Country Data. Third Edition. Geneva: Division of Reproductive Health (Technical Support) WHO. 